\title{
Product Preferences: an Analysis of Instant Uduk Rice
}

\author{
Dwi Kristiastuti Suwardiah ${ }^{\mathrm{a}}$, Febriani Lukitasari ${ }^{\mathrm{b}}$ \\ ${ }^{a}$ Department of Home Economic \\ ${ }^{\mathrm{b}}$ Department of Technical and Vocational Education \\ Universitas Negeri Surabaya \\ Surabaya, Indonesia \\ dwikristiastuti@unesa.ac.id
}

\begin{abstract}
This research study aimed to analyze the quality feasibility of an instant uduk rice product, that was associated with the consumer acceptance study in terms of the preference level. Data analysis techniques with descriptive statistics and Friedman analysis. The results based on consumer preferences in color uduk rice with the highest percentage on the criteria very like by 45,4; Uduk flavored rice based consumer ratings on the criteria very like 59,1\%; Flavour rice uduk based on assessment consumers on the criteria very like 57,7. Texture rice uduk on the criteria very like of 42,3 . The organoleptic test showed that there were significant differences between aluminum foils and plastics packaging for the predilection of color and smell, with the value of 0,046 and 0,006 (less than 5\%). The nutrion of carbohydrate content was the use a manual oven has higher levels (63.86) when electric ovens $(62.44)$, while the fat using the electric oven has the highest content $(12.18 \%)$ when of manual oven (11.86), the protein content in the use of electric oven (10.56) when manual oven is lower $(9.28)$, the highest water content is in the use of manual oven (12.03) then the electric oven (11.32).
\end{abstract}

Keywords-component; Instant uduk rice, quality, consumer preferences

\section{INTRODUCTION}

The rice is a staple food for most people in Indonesia which is consumed in the largest quantity each day. Based on this fact, Indonesian people are difficult to leave or to replace rice with other type of staple food with the same nutrition. Rice consumption as a staple food has psychologically stuck to Indonesian culture in wide area. Either in joy or sadness, people gather together in cultural events with symbols in forms of food whose main ingredient is rice that has been made to be various dishes such as steamed rice, lontong (a rice cake mostly in cylinder shape wrapped inside banana leaves), ketupat (a rice dumpling mostly in diamond shape wrapped inside woven palm leaves), porridge, etc. Those prove that Indonesian people are very dependent to rice as their main staple food, there is even a saying by Indonesian people that if one hasn't eaten rice for a meal, despite the fact that he/she has eaten other types of food and is already full, people will consider that he/she hasn't had a proper meal yet. This is an unbeatable thing that rice has strongly gained its position in Indonesian people's mind as the most top staple food for every day consumption. Rice processing to be $u d u k$ rice/instant flavored rice is an effort to make rice serving to be a lot faster and easier, therefore this instant $u d u k$ rice can be introduced to people as a fast-serving food in emergency conditions such as in a natural disaster, it can also be served as a food supple in a long trip such as Hajj (Islamic pilgrimate), etc. From a search result that has been completed about this instant $u d u k$ rice, this product has several benefits: 1) It contains nutrition which are: Kh $62 \%$, Protein $12 \%$, and fat $11 \%, 2)$ It has fast serving time which is five minutes, 3) It is packed in light packaging so it can be brought everywhere, 4) It is tasty because it contains seasonings and spices [6].

A type of food that can increase human's energy is rice. Rice (Oryza sativa) is a cereal type of food which becomes Indonesian people's staple food. The high production capacity of rice is balanced by the high rate of domestic consumption. Rice consumption rate in Indonesia is $139,5 \mathrm{~kg} / \mathrm{capita} / \mathrm{year}$ in 2009. The high rice consumption rate in Indonesia makes rice as a commodity that has high opportunity to be exploited further in term of processing. Nowadays, rice is commonly processed as cooked rice or porridge. In traditional way, rice processing needs approximately 30 minutes of time to boil it until done. If it's added by the preparation time, this whole process can take up to approximately one hour.

Instant food products in markets nowadays very rarely use rice as their main ingredient. Instant food products that are sold all this time can only give the full feeling to the consumers, not the satisfied feeling. Other processing result from rice is $u d u k$ rice or flavored rice. $U d u k$ rice has been known by Indonesian people especially Javanese ones and it is a traditional dish from Betawi (Jakarta). Consuming uduk rice is not something new for some people. Instant $u d u k$ rice has a potential to be accepted by consumers, thus this product is able to be developed further in bigger production scale.

Instant $u d u k$ rice was produced with aim of creating a food product that is more handy, practical, and ready to eat. This instant $u d u k$ rice product is expected to change people's thought related to the $u d u k$ rice traditional making which takes a lot of time. This research was a further development that has goal of knowing consumers' acceptance and the product's properness level based on its color, smell, taste, and texture or softness, thus it is a necessary to hold a research by creating a bigger scale instant $u d u k$ rice product and still focuses on its nutrient content and good food safety. 
The principal roles of food packaging are to protect food products from outside influences and damage, to contain the food, and to provide consumers with ingredient and nutritional information [14]. Traceability, convenience, and tamper indication are secondary functions of increasing importance. The goal of food packaging is to contain food in a costeffective way that satisfies industry requirements and consumer desires, maintains food safety, and minimizes environmental impact [19].

\section{METHODS}

The redundant research was an experimental one, which aimed to know the properness level of instant $u d u k$ rice product and consumers' acceptance based on the level of preference including: color, smell, taste, and texture. The population scale in this research was a big scale of people, and samples were randomly taken, and the total of samples Wet n137 people as panelists. The research design was a plan created by the researchers where each step was identified as a reference of the research [2].

This is an illustration of the procedure of producing instant $u d u k$ rice:

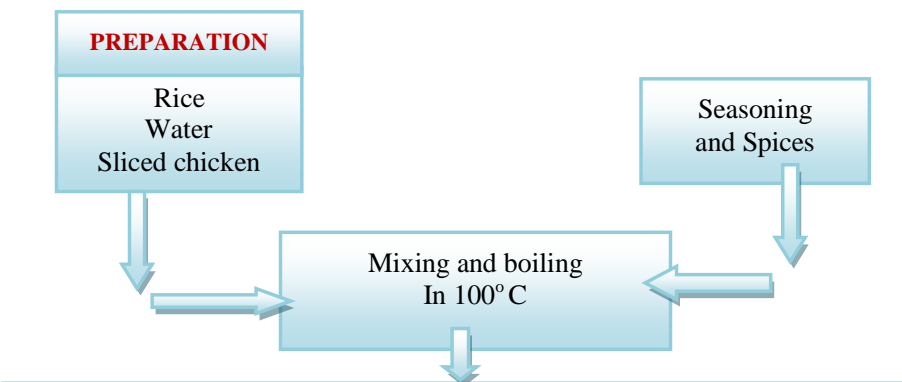

Steaming to $110^{\circ} \mathrm{C}$ for \pm 35 minutes and cooling down to $-5^{\circ} \mathrm{C}$ for \pm 30 minutes

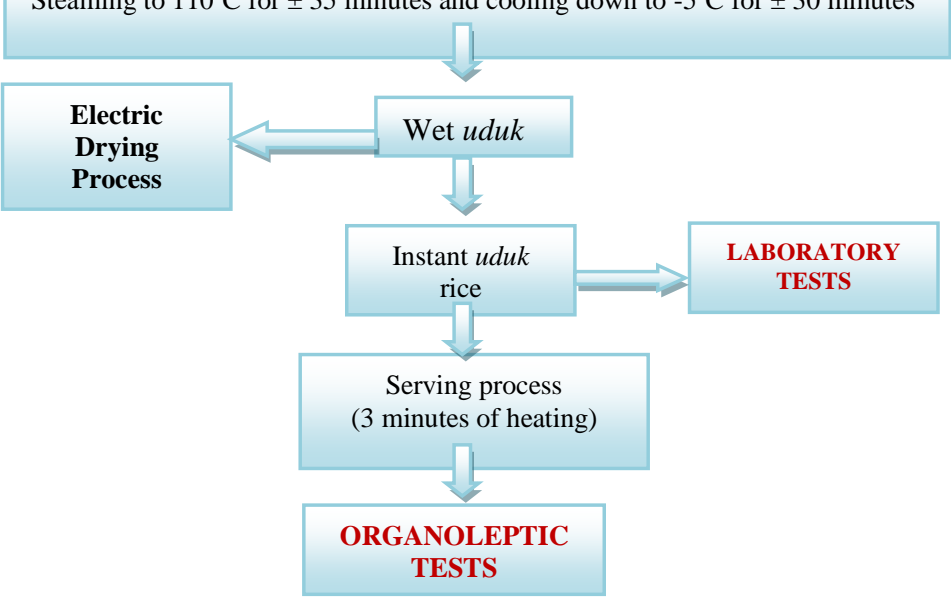

Fig. 1.The prosedur of making instant $u d u k$ rice

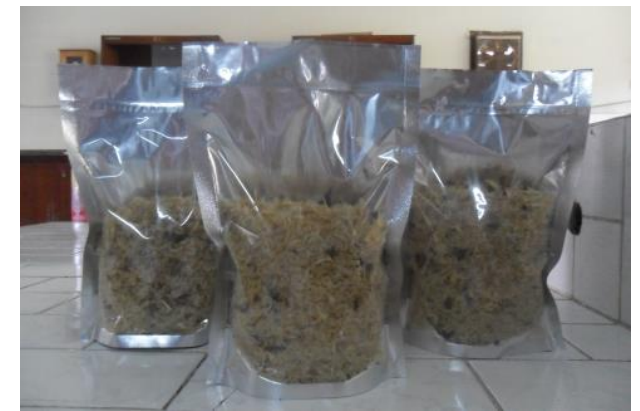

Fig. 2. Product of Instant Uduk Rice

The research design showed one factor, which was the preference level of instant $u d u k$ rice. The design is illustrated as a table below.

TABLE 1. RESEARCH DESIGN OF INSTANT UDUK RICE'S PROPERNESS ANALYSIS

\begin{tabular}{|c|c|c|c|c|}
\hline \multirow{2}{*}{ Sample } & \multicolumn{4}{|c|}{ Criteria } \\
\cline { 2 - 5 } & Y1 & Y2 & Y3 & Y4 \\
& Color & Smell & Taste & Texture \\
\hline$(\mathrm{X})$ & $\mathrm{XY1}$ & $\mathrm{XY2}$ & $\mathrm{XY3}$ & $\mathrm{XY4}$ \\
\hline
\end{tabular}

Note:

$\mathrm{X}$ : The sample of instant $u d u k$ rice product

$\mathrm{Y}(1,2,3,4)$ : Consumers' preference toward the product

In this research, the data collection method used observation method. Observation method is done by performing an organoleptic test to know the product's preference level including: color, smell, taste, texture. The data analysis technique was done by a help of SPSS 18,00 computer program. The data then were analyzed using descriptive statistics percentage and Friedman test to observe the properness level of this product through the consumers' preference level.

\section{RESULTS AND DISCUSSION}

Consumers ratings of instant $u d u k$ rice's properness based on product preference level includes: color, taste, smell, and texture with the criteria of: very fond, fond, fond enough, and less fond. Results data are illustrated as follows.

According to figure 3, there are percentages of consumers' rating for instant $u d u k$ rice's color with the criteria of very fond $45,4 \%$; fond $39,4 \%$; fond enough $9,5 \%$; and less fond $5,8 \%$. The highest criteria was very fond which was $45,4 \%$. This was because the color of dried instant $u d u k$ rice is yellowish that was caused of seasoning and drying process, the original rice's color without seasoning was whie, yet since the rice was mixed with seasoning, chicken broth, and coconut milk then it went through drying process (using an oven), the color turned to yellowish white. Seasoned rice which has gone through cooking process will experience color changing that's influenced by the seasonings, it is because that there is a process of starch browning in dried heating process. 
A. Color

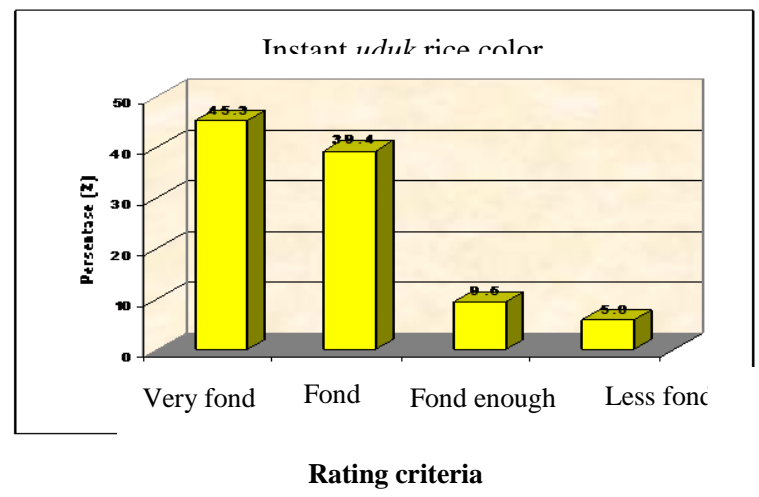

Fig. 3. Consumers rating for instant $u d u k$ rice's color

Less fond

\section{B. Flavor}

Instant $u d u k$ rice flavor

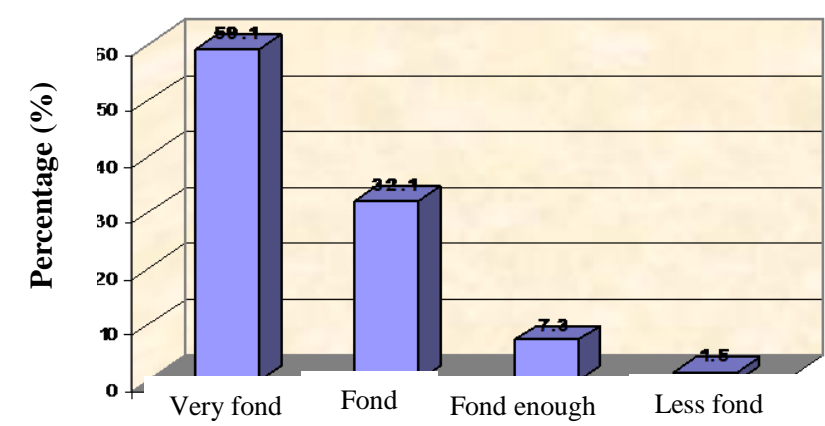

I

Rating criteria

Fig. 4. Consumers' rating for instan $u d u k$ rice's flavor

According to figure 4 there are percentages of consumers' rating for instant $u d u k$ rice's flavor with the criteria of very fond $59,1 \%$; fond $32,1 \%$; fond enough $7,3 \%$; and less fond $1,5 \%$. The highest criteria was very fond which was $59,1 \%$. A taste of a food product both processed and non processed is the climax of that food. The flavor of this instant $u d u k$ rice is influenced by the seasonings and spices that were added to it, such as chicken broth, coconut milk, and sliced chicken. Containing such ingredients, the instant $u d u k$ rice will have savory and delicious taste and will satisfy people who consume it.

\section{Smell}

According to Figure 5, there are percentages of consumers' rating for instant $u d u k$ rice's smell with the criteria of very fond $57,7 \%$; fond $32 \%$; fond enough $8,8 \%$; and less fond $1,5 \%$. The highest criteria was very fond which was $57,7 \%$. The smell of instant $u d u k$ rice comes from the unique characteristics of $u d u k$ rice. In the making process, the rice was added by spices and other ingredients such as sliced chicken, thus a strong smell of those additional ingredients will dominate the product, such as the smell of spices, chicken, and coconut milk which are united to make a very nice and unique smell that makes people to get interested in eating it.

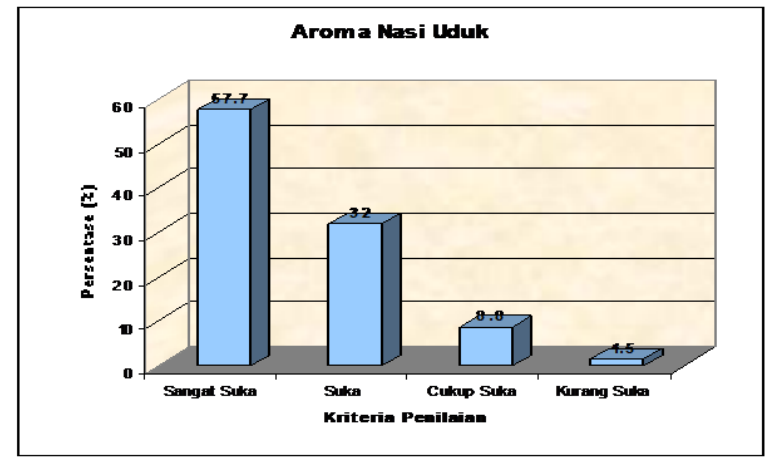

Fig. 5. Consumers rating for instant $u d u k$ rice’s aroma

\section{Texture or Softness}

\section{TEXTURE/SOFTnESS}

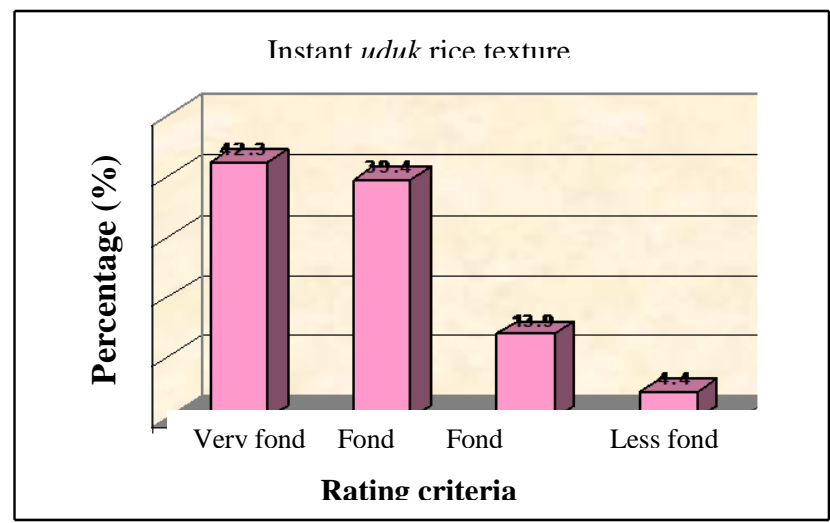

Fig. 6. Consumers rating for instant $u d u k$ rice's texture

According to Figure 6, there are percentages of consumers' rating for instant $u d u k$ rice's aroma with the criteria of very fond $42,3 \%$; fond $39,4 \%$; fond enough $13,9 \%$; and less fond $4,4 \%$. The highest criteria was very fond which was $42,3 \%$. The instant $u d u k$ rice has soft texture and is easy to chew and swallow. The texture is a result of liquid addition (fresh mineral water) the re-cooking for serving, with the ratio of dried $u d u k$ rice and liquid $1: 1,5$. The liquid in re-cooking process is to wet and to increase the volume of starch granules inside the rice grains thus the grains will expand and become soft. This softening process is not too long, which is only three minutes, because rice grains have gone through twice of gelatinization process and the surfaces of the grains are already porious. Besides the amount $f$ liquid, the amount of re-cooking time also determines the instant $u d u k$ rice's texture.

\section{Organoleptic Tests Results}

The result of organoleptic tests toward the properness quality of instant $u d u k$ rice including: color, taste, aroma, and texture/softness are as follows: 
TABLE II. DESCRIPTIVE TEST RESULTS OF CONSUMERS' RATINGS FOR INSTANT UDUK RICE'S PROPERNESS QUALITY

\section{Descriptives}

\section{Pronerness}

\begin{tabular}{|c|c|c|c|c|c|c|c|c|}
\hline & \multirow[b]{2}{*}{$\mathrm{N}$} & \multirow[b]{2}{*}{ Mean } & \multirow[b]{2}{*}{$\begin{array}{c}\text { Std. } \\
\text { Deviation }\end{array}$} & \multirow[b]{2}{*}{$\begin{array}{l}\text { Std. } \\
\text { Error }\end{array}$} & \multicolumn{2}{|c|}{$\begin{array}{l}95 \% \text { Confidence } \\
\text { Interval for Mean }\end{array}$} & \multirow[b]{2}{*}{ Minimum } & \multirow[b]{2}{*}{ Maximum } \\
\hline & & & & & $\begin{array}{l}\text { Lower } \\
\text { Bound }\end{array}$ & $\begin{array}{l}\text { Upper } \\
\text { Bound }\end{array}$ & & \\
\hline Color & 137 & 3.2409 & .85341 & .07291 & 3.0967 & 3.3851 & 1.00 & 4.00 \\
\hline Taste & 137 & 3.4891 & .69786 & .05962 & 3.3711 & 3.6070 & 1.00 & 4.00 \\
\hline Aroma & 137 & 3.4599 & .71758 & .06131 & 3.3386 & 3.5811 & 1.00 & 4.00 \\
\hline Texture & 137 & 3.1971 & .83876 & .07166 & 3.0554 & 3.3388 & 1.00 & 4.00 \\
\hline Total & 548 & 3.3467 & .78854 & .03368 & 3.2805 & 3.4129 & 1.00 & 4.00 \\
\hline
\end{tabular}

\section{Mean of Instant Uduk Rice's Properness Level}

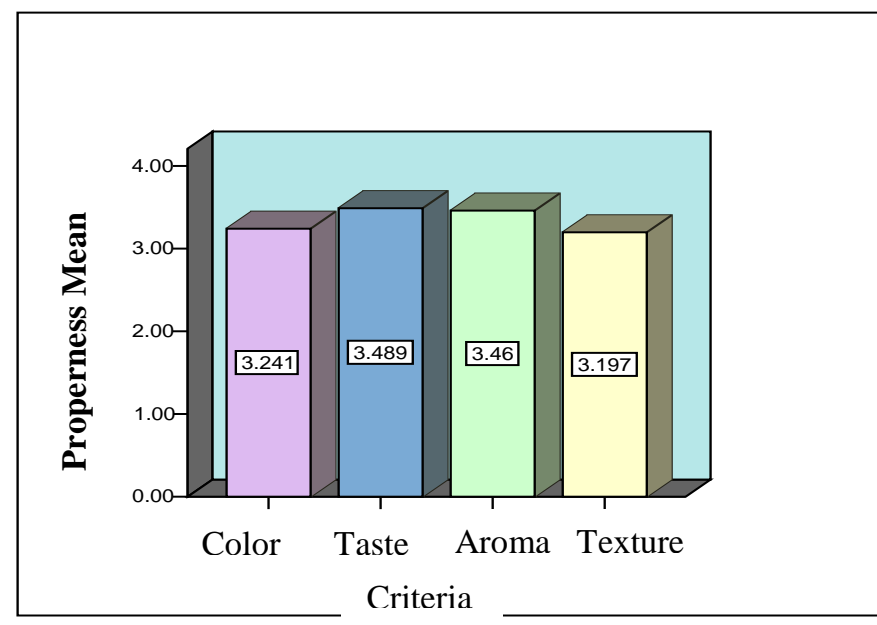

Fig. 7. Properness Mean Value of Instant $U d u k$ Rice

According to table 2 and figure 7. above, the mean value of consumers' ratings for the criteria of color was 3,24; for the taste it was 3,49; for the aroma it was 3,46; and for the texture/softness it was 3,35. The highest mean value was for the taste category which was 3,49 . It is because the taste of instant $u d u k$ rice is unique and savory because of the mixture of spices including candlenuts, garlics, corinders, sugar, salt, lemongrass, orange leaves, bay leaves, chicken broth, and coconut milk. Those spices contain etheric substances that if they're heated, they will produce nice and delicious aroma.

\section{TABLE III. FRIEDMAN TEST RESULT OF INSTANT UDUK RICE'S PROPERNESS LEVEL}

\begin{tabular}{|c|r|}
\hline \multicolumn{2}{|c|}{ Test Statistics $^{\mathbf{a}}$} \\
\hline $\mathrm{N}$ & 137 \\
\hline Chi-Square & 28.566 \\
\hline df & 3 \\
\hline Asymp. Sig. & .000 \\
\hline
\end{tabular}

The Friedman test result in Table 3. showed that all four criteria including color, taste, smell, and texure are influential toward the consumers' acceptance according to the properness level with Chi-Square value of 28,566 and the Asymp.Sig was 0,000 (under 5\%). This means that the hypothesis which stated that there would be influences by all four criteria toward the consumers' acceptance based on the properness level of instant $u d u k$ rice.

\section{CONCLUSION}

Organoleptic tests which was completed to know the properness and fondness level of consumers toward color, aroma, taste, and texture/softness for instant $u d u k$ rice resulted as follows: 1) Research result based on consumers' fondness level toward instant $u d u k$ rice's color had the highest percentage in very fond level which was $45,4 \%$. The criteria of taste had the highest percentage very fond level which was $59,1 \%$. The criteria of aroma had the highest percentage very ind level which was $57,7 \%$. The criteria of texture had the IIIghest percentage very fond level which was $42,3 \%$.. therefore the result of consumers acceptance according to the fondness level in color, taste, aroma, and texture resulted that the product is acceptable for consumers.; 2)Friedman test results showed that all four criteria including color, aroma, taste, and texture/softness are influential toward the consumers' acceptance based on its properness level.

\section{REFERENCES}

[1] Adawiyah, Dede, 2009. Evaluasi Sensoris Produk Pangan (Buku ajar), Bogor : Fak Teknologi Pertanian-IPB.

[2] Arikunto Suharsimi, 2013. Manajemen Penelitian, Jakarta : Rineka Cipta.

[3] Buckle,K.A, dkk, 1987. Ilmu Pangan, Jakarta : UI-PRESS.

[4] Effendi, Samsoeri. 1993. Ensiklopedi Tumbuh-tumbuhan. Surabaya: Karya Anda.

[5] Hubeis, M. 1984. Pengembangan Metode Uji Kepulenan Nasi. Tesis, Pascasarjana IPB, Bogor.

[6] Kristiastuti, Dwi. 2015. Modul Bahan Ajar Pengelolaan Makanan Nusantara. Unesa.

[7] Luh, B.S., R.L. Robert and C.F. Li. 1980. Quick Cooking Rice. Di dalam Luh, B.S. (Ed). Rice Production and Utilization. AVI Publ. Comp. Inc. Westport. Connecticus.

[8] McNeely, Jeffrey A. 1992. Economi dan keanekaragaman hayati, Jakarta: Sinar Harapan.

[9] Rewthong, O., S. Soponronarit, C. Taechapairoj, P. Tungtrakul and S. Prachayawarakorn. "Effect Of Cooking, Drying And Pretreatment Methods On Texture And Starch Digestibility Of Rice Instan". J Food Eng 103, 2011. pp 258-264.

[10] Soedarmo, Poerwo. 2010. Ilmu Gizi. Jakarta: Dian Rakyat.

[11] Suyitno dkk, 1989. Rekayasa Pangan ( Petunjuk Laboratorium), Yogyakarta : PAU UGM.

[12] Wahono, Francis, dkk. 2010. Pangan kearifan lokal dan keanekaragaman hayati. Yogyakarta: Cindelaras Pustaka Rakyat Cerdas.

[13] Mr. Nehal A. Shah et, 2012. "Study of consumers preferences \& its affecting factors towards selection of various noodles of branded companies in ahmedabad city". ISSN 2349-2317 (Online) Volume 3 Issue 4.

[14] Chowladda,et.al, 2011. 'The production and shelf life of high-iron, precooked rice porridge with ferrous sulphate and other high-iron materials'. ISSN 1905-7873, Maejo Int. J. Sci. Technol. 2011, 5(02), pp 279-291,

[15] Hasan,et.al. 2008. "Study on the period of acceptability of cooked ric". ISSN 1810-3030, J. Bangladesh Agril. Univ. 6(2): 401-408. 
[16] E.Ahmed, et.al. 2016, 'Rice noodles: materials, processing and quality evaluation'. Proceedings of the Pakistan Academy of Sciences: Pakistan Academy of Sciences B. Life and Environmental Sciences 53 (3): 215-238 (2016), ISSN: 2518-4261 (print), ISSN 2518-427X (online).

[17] Chitapallo, et.al. 2016. "Product development of black glutinous rice cracker with Panang flavor and its quality changes", International Food Research Journal 21(5): 2014. Pp 2025-2029.

[18] Meihua, et.al."Process optimization and its impacts on physical properties of instant rice". Advance Journal of Food Science and Technology 5(4): 464-468, 2013 ISSN: 2042-4868; e-ISSN: 2042-4876.

[19] Kenneth, et.al, 2007. "Food Packaging-Roles, Materials, and Environmental Issues”. Vol. 72, Nr. 3, 2007, Journal Of Food Science.
[20] Orrawan, et.al. 2011. "Effects of cooking, drying and pretreatment methods on texture and starch digestibility of instant rice". Journal of Food Engineering 103 258-264.

[21] Chim,et.al. 2007. "Traditional dried starter culture (Medombae) for rice liquor production in Cambodia”. International Food Research Journal 22(4): 1642-1650 2015. Journal homepage: http://www.ifrj.upm.edu.my.

[22] Marlia, et.al. "Determinants of Consumers Purchasing Behavior for Rice in Malaysia". American International Journal of Contemporary Research. Vol. 1 No. 3. 2011.

[23] Bala, et.al. 2012. "Buying behaviour of consumers towards instant food products". International journal of Research and computational Technology, Vol.2 Issue 2, May, 2012 ISSN: 0975-5465 